\title{
Local (Malaysian) Leech as Alternative Healing Treatment and an Islamic Perspective
}

\author{
ZULHISYAM, A. K*., AHMAD ZAKI AMIRUDDIN, JAMALUDIN, M. H., LEE S. W. \\ \& WAN YUSOFF, W. S. ${ }^{1}$
}

\begin{abstract}
The therapy is known from the time of extreme antiquity, dating back more than 2,500 years ago and still being practiced nowadays. This fact testifies to its efficiency in various health problems. In some cases, traditional medical practitioners use leeches for therapeutic healing treatment which is known as 'cupping'. Such remedial method is quickly gaining acceptance amongst the local folks which is now becoming a thriving business. Some have made this treatment as their main business even though the therapy is quite recent for people in this country. This article discusses the process of cupping by using leech in the Islamic perspective and also the uniqueness of the hirudin protein in leeches respectively.
\end{abstract}

Keywords: alternative medicine, hirudin protein, Islam and medicine, leech

Leeches (Phylum: Annelida, Class: Hirudinea) are widely distributed all over the world in diverse habitats, such as freshwater, seas, deserts, and oases (Gouda 2006). They can be predators, vectors of parasites, or even prey of other aquatic animals (Saywer 1986a; Keim 1993). In recent years, the population of leeches have declined dramatically due to over-exploitation for fishing bait and medicinal purposes (particularly in Europe and Asia), and due to pollution (Sawyer, 1981; Elliot \& Tullett 1984; Wells \& Coombes 1987; Petrauskiene 2003; Trontelj \& Utevsky 2005). Leech therapy is one of the most important and widely practiced methods of regimental therapy used for local evacuation of morbid tumors (Ibn Sina 1998). The therapy is known from the time of extreme antiquity, more than 2,500 years ago and is still being practiced until now. This fact testifies to its efficiency in various health problems. In Malaysia, the entrepreneurs use leeches as trading animal and they are exported to meet the demand in countries such as Korea, Ukraine, China and Spain. Normally, the leech products are exported in the dried form approved and certified by the Department of Fisheries, Ministry of Agriculture and Agro Based Industry, Malaysia. However, there are also a handful of unscrupulous entrepreneurs who used leeches for personal gain by deceiving the public in traditional medicine. This action on their part can harm the leech farming industry and cause hesitation amongst the local folks on the viability of the industry for new entrepreneurs who want to venture in this field.

\footnotetext{
${ }^{1}$ Zulhisyam Abdul Kari @ Abdullah*(Corresponding author), Mohd Hafiz Jamaludin \& Lee Seong Wei, lecturers at Faculty of Agro Based Industry, Universiti Malaysia Kelantan, Jeli Campus, Locked Bag No. 100, 17600 JELI, Kelantan, Malaysia, email: zulhisyam.a@umk.edu.my, hafiz@umk.edu.my, leeseong@umk.edu.my; Ahmad Zaki Amiruddin \& Wan Yusoff Wan Shaharuddin, lecturers at Centre for Language Studies \& Generic Development, Universiti Malaysia Kelantan, Jeli Campus, Locked Bag No. 100, 17600 JELI, Kelantan, Malaysia, email: ahmadzaki@umk.edu.my, yusoff.ws@umk.edu.my.
}

https://doi.org/10.24035/ijit.10.2016.007 
Leeches have been used for centuries in the treatment of variety of diseases, including thromboembolic disorders and inflammatory states. With the advent of modern medicine, leeching is slowly demising, yet interest in the medicinal use of the leech are still demanding. Leeches have been used successfully to restore the flow of blood in microcirculation after plastic surgery (Mutimer et al. 1987).

\section{Local Leech Status and Issue}

Leeches is a sanguivorous (haemopagic), freshwater leech, with a wide distribution in Southeast Asia such as in southern China, the Philippines, Thailand, Vietnam, and Malaysia. In Malaysia, these leeches are known as 'Lintah Kerbau' (406 th Medical Lab. Special Repor, 1968). There has been numerous collection of this species for medical purposes in the 20th century (Steiner et al. 1990; Electricwala et al. 1993; Singhal \& Davies 1996). The Department of Wildlife Protection and National Parks (PERHILITAN) previously operated the leech industry in Malaysia. Since 22nd of January 2009, the Department of Fisheries Malaysia has taken over the operation of local leech's industry (Department of Fisheries Malaysia 2009). The Fisheries Department have since identified the leech species that can be used for commercial purposes. The taxonomic status of the local leech is as follows: Order: Hirudinea; Species: Hirudinaria manillensis; Local name: Buffalo leech or "lintah kerbau" (Figure 1).

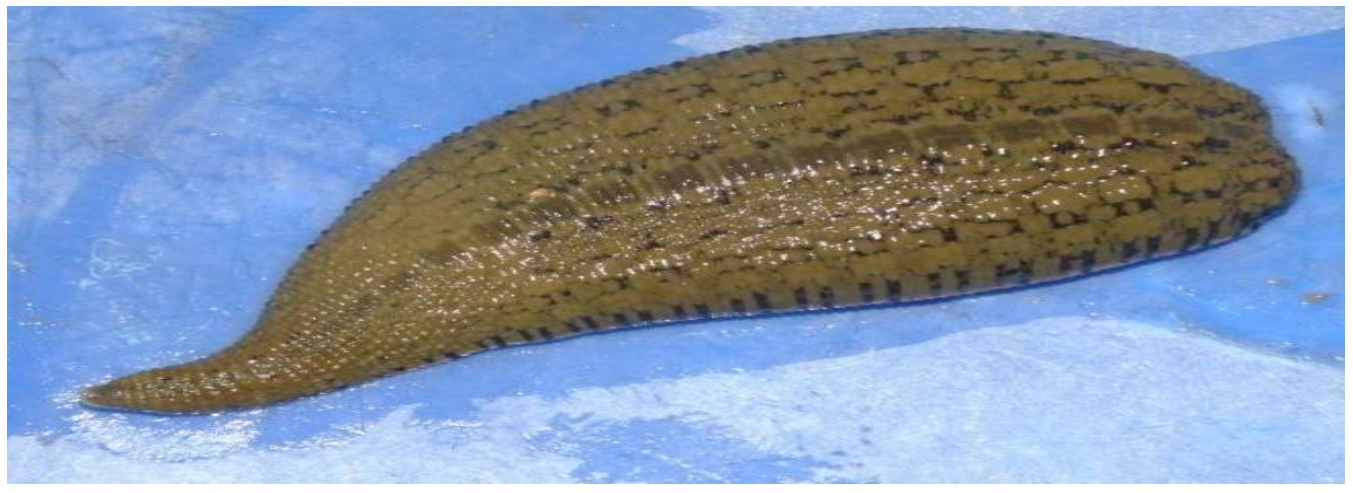

Figure 1: Body of Local Leech (Age: Two Years and Three Months)

However, it is not known or proven conclusively that the locally named Buffalo Leech is not of $H$. manillensis although this has been confirmed by Department of Fisheries Malaysia. In addition, local taxonomists have not been able to identify the species used for medicinal purposes (Rosly Hassan April 2, 2010).

In Malaysia, there are two types of different local species namely "dark brown buffalo leech" and "green buffalo leech" (Figure 2 and 3) (Zulhisyam A.K. et al. 2014). Previously, the folks used a green buffalo leech for medical purposes especially for cupping treatment. Nevertheless, there are also entrepreneurs that used a dark brown local leech for medical purposes without knowing the basic protein function between the species. However, in Malaysia researches on gathering more information of the hirudin protein is still far and between. 

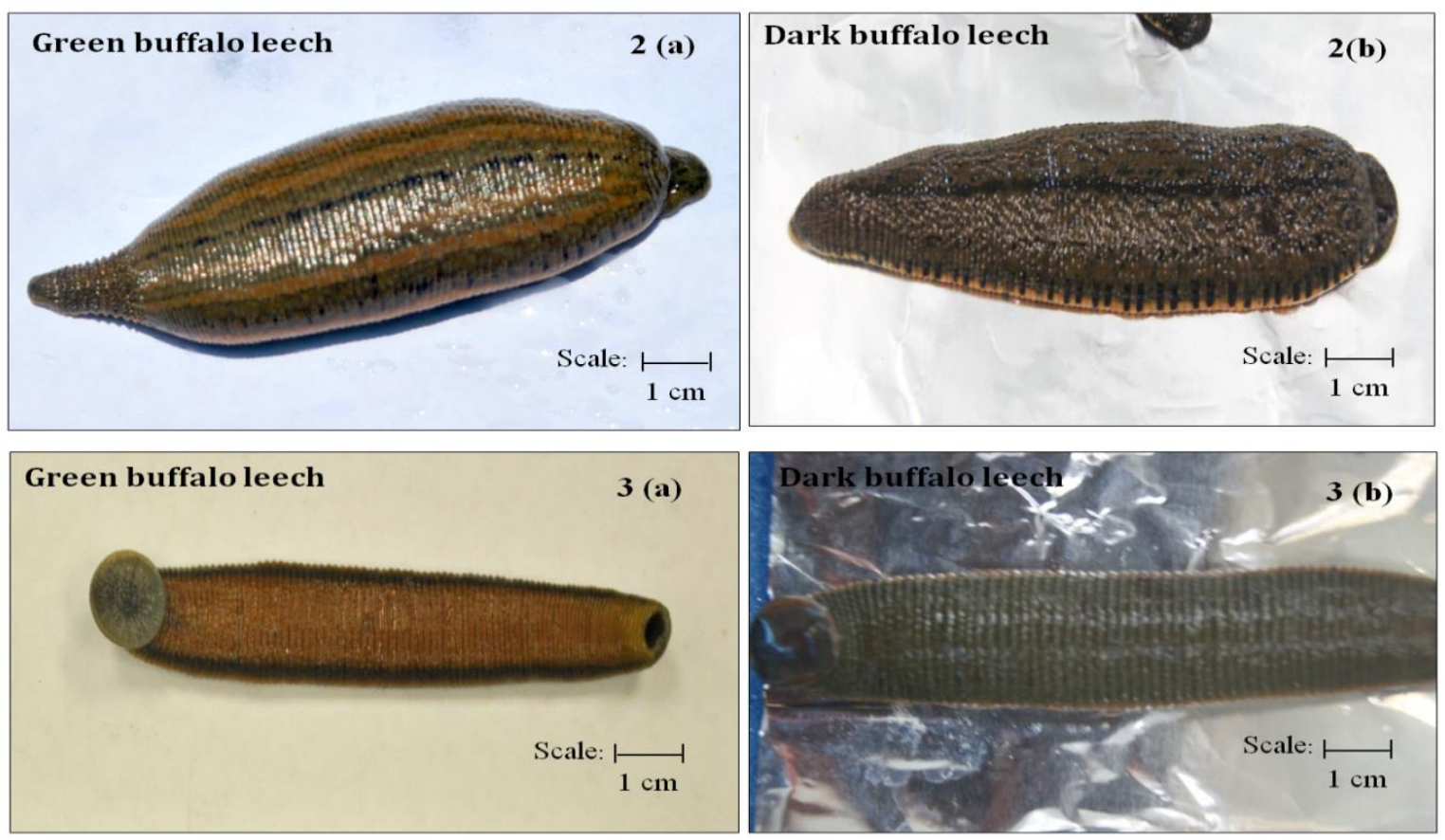

Figure 2: Comparsion of Body Color and Pattern on Dorsal and Onventral Sides

\section{Cupping from the Islamic Perspective}

Leech therapy is one of the most important and widely practiced methods of regimental therapy used for local evacuation of morbid tumors (Ibn Sina 1998). Today, there are many products which have been derived from leeches for pharmaceutical and medicinal purposes in and around also the world. Without realizing, many of our own entrepreneurs have also made their work and some have already exported their products to overseas markets which augur well for this new industry. In order to meet the demand for clinical use in Chinese traditional medicine and other scientific research, there has been growing interest in culturing and breeding of leeches in many countries (Yang 1996; Trontelj \& Utevsky 2005)

Leeches are forbidden (haram) for consumption as food, but it is recommended (sunnah) for cosmetic purposes and as medicinal remedy (Mohd Amri Abdullah June 10, 2009). Nowadays, the breeding of leeches for medical purposes has bright commercial potential and of late, many entrepreneurs have embarked on the farming of leeches. Besides that, the Malaysian National Fatwa Council of Islamic Affairs which have had a meeting on the 31st of March 2007 has come out with an edict that the usage of worms and leech should be encouraged. From Abu Hurairah (r.a.), the Prophet Muhammad (s.a.w.) said:

Allah will not deliver any disease but He also reveal to him (namely, the disease is) the cure or remedy (al-Bukhari, Sahih al-Bukhari, Kitab al-Tib, Hadith No. 5354).

Imam Ibn Hajar al-Asqalani (1883) when explaining the said hadith, stated that the disease mentioned is the disease of the body, and for every diseases, there is a cure or remedy which can be obtained: 
1. Directly from what was given by the Prophet through his Sunnah, either qawliyyah (saying), fi'liyyah (action) and taqririyyah (consensus).

2. Through experience and knowledge; either fitrah (naturally) which has been provided by Allah to an individual by benefiting from nature, or through thinking, research and experimentation until a cure or remedy is obtained for a specific disease (as what medical experts are doing today).

An example of remedy shown by the Prophet Muhammad (s.a.w.) is cupping, as revealed by his sayings:

From Ibnu Abbas RA, from the Prophet Muhammad said: "A cure or remedy is from three occasions, (which is); from a cut for cupping, or taking honey, or from hot iron (using heat from fire), but I (the Prohet) prohibit my ummah from using (treating using) hot iron" (al-Bukhari, Sahih al-Bukhari, Kitab al-Tibb, Hadith No. 5357).

From Humaid, he said; Anas bin Malik was asked on the subject of cupping, and he answered: "Rasulullah (s.a.w.) did perform cupping, and his cupper was Abu Thaibah, he requested Abu Thaibah to be given (paid) 2 measurement of food, as told to his family (the family of Abu Thaibah), and they (agreed) did not request payment (wage for himself or to free him from a certain agreement). Than the Prophet said, "the best remedy or cure that you can use to remediate or cure is through cupping". Or (the Prophet); "cupping is one of the form of remedy and cure that is the best for all of you." (Muslim, Sahih Muslim, Kitab al-Masaqah, Hadith No.4121).

Through the hadith above, cupping is considered one of the remedial or curing methods encouraged by the sunnah, as well as one of the practice that is categorized as one of the best medical techniques. The hadith narrated by al-Bukhari explains in general three techniques, but only two are recommended, which is cupping and taking honey (the third has been prohibited, which is the hot iron technique). Meanwhile the hadith narrated by Muslim explains in detail cupping as one of the best medical techniques. Other than that, the hadith also mentioned that wage must be given to the cupper (al-Nawawi 1392H).

\section{The Islamic Perspective on the Use of Leech in Cupping}

The practice of the sunnah and modern research today has provided the potential technique of cupping using leaches. Although it looks different from traditional cupping, there is no wrong in this practice from a religious perspective. This is in line with the explanation that was given earlier. For the source of remedy and cure, what Islam condones is what has been revealed by the prophet or through experience or research from the benefit of nature.

The use of leach in cupping is one example of alternative medicine. This technique is considered as the worldly knowledge that is allowed, as long as it does not break the rule of the Islamic law (syariat). This is guided by hadith of Anas narration, the Prophet went past a group of farmers who are busy pollinating (date palm), the Prophet exclaimed: "If they would not do thus, then it would still come out right." The date crop that resulted was of a very poor quality. Then he passed by them and asked: "What is with your date palms?" They said: "you had told us such and 
such." the Prophet replied: "You know best the affairs of your worldly life". (Hadith narrated by Muslim)

Imam Muslim placed this hadith in the chapter "The obligation to follow the message of the Prophet in activities associated with the syarak (Islamic Jurisprudence), and (it is not wrong if it is not followed) in things associated with worldly affairs. In regards to this chapter, it is understood that Islam provides the space to make one's own decision in the management of worldly affairs, especially concerning worldly progress.

Thus, the use of leaches in cupping is considered a form of improvement in medical techniques (cupping) that is approved by the Prophet as a form of remedy and cure. In this instance, cupping is considered as a sunnah (Prophet's practice), with the only difference is in the technique that is in line with the Islamic law.

It is hoped that the practice of cupping which is approved by the Prophet (s.a.w.) by a few jurisdictions that has been revealed through him. With the incorporation of the knowledge of man which has been given the ability to think, the practice of cupping should become better. Any form of sunnah will bring positive impact to both physical and the mental state of the person who practices it.

\section{Leech Uses in Medicine}

Traditionally, leeches are widely used as a model animal in toxicological, physiological, neurobiological, biochemical, histological and many other studies (Mann 1962a; Flerov \& Lapkina 1976; Lapkina \& Flerov 1979; Sawyer 1986a; Lapkina 1992; Huguet \& Molinas 1992 \& 1996; Blackshaw \& Nicholls 1995; Petrauskienè 2001). The use of leeches for clinical or medicinal purposes (e.g. blood-letting) has occurred since the 5th century BC, with considerable usage in the 19 th century, followed by a decline in the early 20th century (Kasparek et al. 2000). However, in recent years, the medically beneficial usage of leech is once again increasing (Baskova et al. 1983; 1992). For example, $H$. medicinalis is used by plastic surgeons to restore venous circulation in tissue grafts where blood stagnation is a problem (Sawyer 1986b; Rigbi et al. 1987; Roters \& Zebe 1992; Whitaker et al. 2004; Huang et al. 2006b).

Extracts (i.e. hirudin) from this species have been shown to have an important thrombolytic effect on experimental thrombosis (Tan \& Liu 2002; Huang et al. 2006a, 2006b; Li et al. 2006). There has been an increasing collection of this species for medicinal purposes in the 20th century, and this, combined with a general loss and pollution of wetland habitats have caused a dramatic decline of $H$. manillensis throughout its geographical range (Steiner et al. 1990; Electricwala et al. 1993; Singhal \& Davies 1996).

\section{Hirudin Protein in Leech}

It is a common knowledge that when the leech ceases to feed, the host bleeds for a long time. It has long been known that leeches contain a substance with anticoagulant properties namely hirudin protein. Numerous studies with experimental animal models have been performed that corroborated the antithrombotic efficacy of hirudin (Kaiser 1991). However, in Malaysia work on gathering more information on hirudin protein is still far and between.

Many studies have been conducted to determine the molecular structure of hirudin but it is not confirmed if the species observed by Gruetter et al. (1990) is similar to the Buffalo leech. He found that hirudin from the leeches contained numerous acidic amino residues except for methionine, tryptophan, alanine or argine. According to Bagdy et al. (1976) the structure of hirudin has some unique features. There are three disulphide linkages located within the first $39 \mathrm{~N}$ - 
terminal residues of native hirudin. Hirudin contains a highly acidic C-terminal segment. There are 5 acidic amino acids, $4 \mathrm{Glu}$ and one Tyr-SO3H, within the last $9 \mathrm{C}$-terminal residues. Jui-Yoa Chang (1983) emphasized that removal of the acidic C-terminal amino acids of native hirudin by both chemical and enzymatic methods resulted in a concomitant loss of hirudin inhibition activity.

The analysis of the anticoagulant effect of hirudin has shown that it is a selective inhibitor which is highly specific for $\alpha$-thrombin according to the different time taken for blood to clot. According to Markwardt (1992) hirudin protein forms tight stoichiometric complexes with thrombin whereby the active centre of the enzyme is blocked (Figure 2). The complex formed is very stable in the physiological pH range but can be dissociated by acidification or heating, whereby thrombin is denatured and hirudin released in its active form (Markwardt 1970).

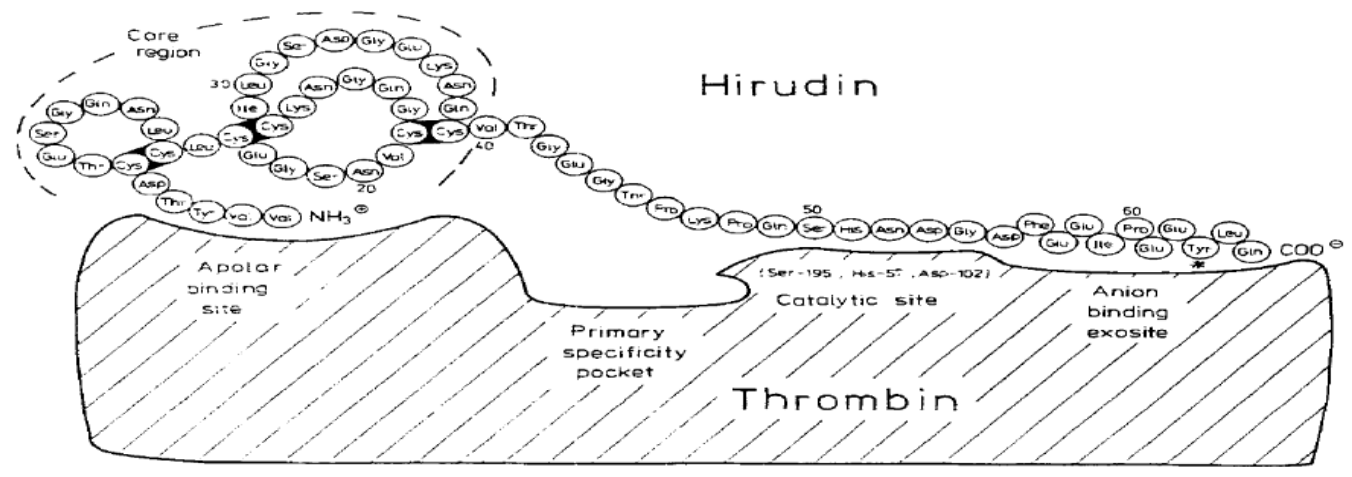

Figure 3: Scheme of the hirudin interaction with the active site of thrombin (Markwardt 1992). According to Zulhisyam (2012) the study revealed that the molecular weight of the protein was about $11.36 \mathrm{kDa}$ and the anti-coagulant agent is only found in the head of leeches (salivary glands)

\section{Problems in the Leech Industry}

In order to place the leech industry as a potential industry, there are a lot of factors that need to be known and explored. Several factors determine leech distribution in freshwater environments such as availability of food organisms; nature of the substrate; depth of water; presence of water currents; size and nature of the body of water; hardness and $\mathrm{pH}$; temperature of the water; dissolved oxygen; siltation and turbidity; and salinity (Sawyer 1986b). However, there are less numbers of studies attempting to investigate the factors affecting growth and production of leeches in this country particularly the effect of water, temperature, dissolved oxygen, $\mathrm{pH}$, and light intensity on growth performance of these leeches bred in a farm as well as their feeding requirements. Understanding the growth conditions, reproduction and development required could help maximize the quality of leech farming and those for medical purposes.

Leech farming is seen as a solution to the growing demand for the production of leeches throughout the world. Modern leech therapy differs from that of an ancient one because wild leeches are not used in the recent method. The leeches are grown at special leech farms where they are subjected to severe quarantine requirements. In addition, to exclude infection on to the patient a leech is used only once and thrown away after the treatment has ended. In this country, largesized leeches are usually used for breeding and production while small-sized leeches (2-3 week juveniles) are used for "cupping" therapy. As it is known, until now the leech's supply is always insufficient and this problem is sometime has caused many entrepreneurs to discontinue their business for a temporary period due to the lack of leeches. If this shortage of leech supply 
continues, there may be causing negative effects on the economy as well as on the entrepreneurs. In order to address this problem of uncertainly and shortage of supply of local leeches, optimization of their growing condition is highlyrecommended.

With the rapid expansion of leech-based industries, the request for supply of leeches has increased tremendously. The present source of obtaining leeches from the wild are fast depleting and far in between and as such some interested parties have taken the initiative to organize training and workshop on leech rearing and breeding. Some of them also offer contract farming package. To date, there are various culturing methods that have been introduced but more have come out with a standard practice method of leech farming on a viable commercial basis involving all components in the breeding and rearing of local leeches. Among the constraints identified are there has been very little research done to date on ways to proceed with large-scale production of leeches on a sustainable basis and couple with the lack of scientific information to support the industry.

In this country, there is no proper standard or guide on how leech farming should be carried out and this problem has led to the difficulty for entrepreneurs to handle breeding on large scale besides the fact that a few of them did not succeed in the leech industry as the leeches failed to reproduce well. This problem arose because the entrepreneurs are not aware of the basic practice that should be included in the breeding of leeches and the uncertainties in leech growth condition, which causes an ineffective product in leech farming. Therefore, this study needed to investigate the optimum growing condition for culturing local leeches for hirudin production.

As a conclusion, leeches are valued today for scientific study, largely related to their nervous system, and for several specific aspects of phlebotomy. The availability of now opens the door for more detailed studies on its pharmacological properties in experimental for clinical settings and also for business to create contract farming among people. In order to boost the leech industry in Malaysia, all parties should play their role well, especially researcher and also the entrepreneurs. The function and characterization of protein hirudin in leech can be the main factor of leech to become a good cupping treatment.

\section{Acknowledgments}

The authors are grateful to the Faculty of Agro-Based Industry, Universiti Malaysia Kelantan for providing space and facilities to carry out the study. This study was funded by Ministry of Higher Education, MALAYSIA vote of R/RAGS/A07.00/00778A/001/2015/000214 and supported by PT Dynamic Consultant Co., Kota Bharu, Kelantan.

\section{References}

Bagdy, D., Barabas, E., Graf, L., Peterson, T. E., \& Magnusson, S. 1976. Hirudin methods enzymol. Protein Science 45: 669-78.

Baskova, I. P., Cherkesova, D. U., \& Mossolow, V. V. 1983. Hirudin from leech head and whole leech and "pseudo hirudin" from leech bodies. Thrombosis Research 30: 459-467.

Baskova, I. P., Khalil, S., Nartikova, V. F., \& Paskhina, T.S. 1992. Inhibition of plasma kallikrein, kininase and kinin-like activities of preparations from the medicinal leeches. Thrombosis Research 67 (6): 721-730.

Blackshaw, S. E., \& Nicholls, J. G. 1995. Neurobiology and development of the leech. Journal of Neurobiology 27(3): 267-276. 
al-Bukhari, Abu 'Abd Allah Muhammad bin Isma'il al-Ja'fi. 1987. Al-Jami' al-Sahih al-Mukhtasar. Vol. 5. Beirut: Dar Ibn Kathir.

Department of Fisheries Malaysia. 2009. Penukaran Jabatan Teknikal Bagi Pengurusan Permit Eksport/Import dan Angkut untuk Lintah dari PERHILITAN ke Jabatan Perikanan Malaysia. Putrajaya: Government Printing Office.

Electricwala, A., Hartwell, R., Scawen, M. D., \& Atkinson, T. 1993. The complete amino acid sequence of a hirudin variant from the leech Hirudinaria manillensis. Journal of Protein Chemistry 12(3): 365-370.

Elliott, J. M. \& Tullett, P .A. 1984. The status of the medicinal leech Hirudo medicinallis in Europe and especially in the British Isles. Biological Conservation 29(1): 15-26.

Flerov, B. A., \& Lapkina, L. N. 1976. Avoidance of some toxicants by medicinal leech. Information Bulletin IBVV 30: 48-52.

Gouda, H. A. 2006. The effect of peritrich ciliates on some freshwater leeches from Assiut, Egypt. Journal of Invertebrate Pathology 93: 143-149.

Gruetter, M. G., Priestle, J. P., Rahuel, J., Grossenbacher, H., Bode, W., Hofsteenge, J., \& Stone, S. R. 1990. Crystal structure of the thrombin-hirudin complex: A novel mode of serine protease inhibition. Journal of European Molecular Biology Organization 9: 2361-2365.

Huang, A. M., Li, Z. Y., Liao, G. S., \& Ban, J. D. 2006a. Purification of anti-coagulant protein from digestive juice of Guangxi Hirudinaria manillensis. Chinese Journal of Biochemical Pharmaceutics 27(5): 273-276.

Huang, A. M., Li, Z. Y., Liao, G. S., Huang, H. K., Ban, J. D., \& Lin, F. Q. 2006b. The anticoagulant effect of Bufrudin on human plasma in vitro and rabbit plasma in vivo. Journal of Guangxi Medical University 23(1): 30-32.

Huguet, G., \& Molinas, M. 1992. Changes in epithelial cells in Hirudo medicinalis during wound healing. Journal of Invertebrate Pathology 59: 11-17.

Huguet, G., \& Molinas, M. 1996. Myofibroblast-like cells and wound contraction in leech wound healing. Journal of Experimental Zoology 275: 308-316.

Ibn Sina. 1998. Al-Qanun fi al-Tib. 2nd edition. Transl. by Mazhar H. Pasha. n.l.: Inter Services Press.

Jui-You Chang. 1983. The functional domain of hirudin, a thrombin-specific inhibitor. Pharmaceutical Research Laboratories. Switzerland: Ciba-Geigy Ltd, Basel CH-4002.

Kaiser, B. 1991. Anticoagulant and antithrombotic actions of recombinant hirudin. Journal of Thrombosis and Hemostasis 17: 130-6.

Kasparek, M., Demirsoy, A., Akbulut, A., N. E., Çalişkan, M., \& Durmuş, Y. 2000. Distribution and status of the medicinal leech (Hirudo medicinalis L.) in Turkey. Hydrobiologia 441: 37-44.

Keim, A. 1993. Studies on the host specificity of the medicinal blood leech Hirudo medicinalis $L$. Parasitology Research 79: 251-255.

Lapkina, L. N. 1992. Comparative study of lethal and sublethal effects of trichlorphon on leeches. Information Bulletin IBVV, RAN 94: 67-73.

Lapkina, L. N., \& Flerov, B. A. 1979. Impact of some toxicants on leech in acute toxicity test. Proceedings Freshwater Biology Institute Academic Science USSR 38(41): 50-59.

Li, Y. H., Yang, Y., \& Li, Z. Y. 2006. The antithrombotic effect of extract from the Guangxi Hirudinaria manillensis on animal thrombisis. Journal of Guangxi Medicinal University 23(6): 901-903.

Mann, K.H. 1962. Leeches (Hirudinea). Their Structure, Physiology, Ecology and Embryology. London: Oxford University Press.

Markwardt, F. 1970. Hirudin as an inhibitor of thrombin. Methods Enzymol 19: 924-32.

Markwardt, F. 1992. Hirudin the promising antithrombotic. Cardiovascular Drug Reviews 10(2): 221-232. 
Mohd Amri Abdullah. 2009. HDC Industry Development Corporation, S.B, 5.02 Level 5 KPMG 1st Avenue, Persiaran Bandar Utama, Bandar Utama, 47800 Petaling Jaya. Interview. June 10.

Mutimer, K. L., Banis, J. C., \& Upton, J. 1987. Microsurgical reattachment of totally amputated ears. Plastic Reconstructive Surgery 2: 535-540.

Muslim, Abu al-Husayn bin al-Hajjaj bin Muslim al-Qushayri al-Naysaburi. Al-Jami'al-Sahih: Sahih Muslim. Vol. 5. Beirut: Dar al-Jil.

al-Nawawi, Abu Zakariya Muhyiddin Yahya bin Syaraf. 1392H. Kitab al-Minhaj Syarah Sahih Muslim bin al-Hajjaj (Syarh al-Nawawi 'ala Sahih Muslim). Beirut: Dar Ihya al-Turath al-'Arabiyy.

Petrauskienè, L. 2001. Water and sediment toxicity assessment by use of behavioural responses of medicinal leeches. Environment International 28: 729-736.

Petrauskienè, L. 2003. Water toxicity assessment using medicinal leeches. Aquatic Ecosystem Health \& Management. 4: 203-208.

Rigbi, M., Levy, H., Iraqi, F., Teitelbaum, M., Orevi, M., Alajoutsijärvi, A., Horovitz, A., \& Galun, R. 1987. The saliva of the medicinal leech Hirudo medicinalis I. Biochemical characterization of the high molecular weight fraction. Comparative Biochemistry and Physiology. Part B. Biochemistry and Molecular Biology 87(3): 567-573.

Rosly Hassan. 2010. Pusat Penyelidikan Perikanan Air Tawar, Bahagian Penyelidikan, Jabatan Perikanan Malaysia. 71650 Titi, Jelebu, Negeri Sembilan. Interview. April 2.

Roters, F. J., \& Zebe, E. 1992. Proteinases of the medicinal leech, Hirudo medicinalis: purification and partial characterization of three enzymes from the digestive tract. Comparative Biochemistry and Physiology. Part B. Biochemistry and Molecular Biology 102: 627-634.

Sawyer, R. T. 1970. Observations on the natural history and behavior of Erpobdella punctata (Leidy) (Annelida: Hirudinea). American Midland Naturalist 83(1): 65-83.

Sawyer, R. T. 1986a. Leech Biology and Behavior. New York: Oxford University Press.

Sawyer, R. T. 1986b. Leech biology and behavior II. Feeding Biology, Ecology and Systematics. Oxford: Clarendon Press.

Singhal, R. N., \& Davies, R. W. 1996. Effects of an organophosphorus insecticide (Temephos) on gametogenesis in the leech Hirudinaria manillensis (Hirudinidae). Journal of Invertebrate Pathology 67(1): 100-101.

Steiner, V., Knecht, R., Gruetter, M., Raschdorf, F., Gassmann, E., \& Maschler, R. 1990. Isolation and purification of novel hirudins from the leech Hirudinaria manillensis by high-performance liquid chromatography. Journal of Chromatography B: Biomedical Sciences and Applications. 530: 273-282.

Tan, E.G., \& Liu, X.P. 2002. Cloning and sequencing of Hirudin gene of Hirudinaria manillensis in Guangdong, China. Academic Journal SUMS 23(2): 84-86.

Trontelj, P. \& Utevsky, S.Y. 2005. Celebrity with a neglected taxonomy: molecular systematics of the medicinal leech (genus Hirudo). Molecular Phylogenetics and Evolution 34: 616-624.

Wells, S., \& Coombes, W. 1987. The status of and trade in the medicinal leech. Traffic Bulletin 8: 6469.

Whitaker, I.S., Izadi, D., Oliver, D. W., Monteath, G. \& Butler, P. E. 2004. Hirudo medicinalis and the plastic surgeon. British Journal of Plastic Surgery 57: 348-353.

Yang, T. 1996. Fauna Sinica (Annelida Hirudinea). Beijing: Science Press.

Zulhisyam A.K., A. Anwar Ismail \& Ibrahim Che Omar. 2012. Detection and purification of hirudin protein from local leeches using Gel Filtration Chromatography (Sephadex G-75). Journal of Bioentrepreneurship 2(2): 44-54.

Zulhisyam, A. K.JJamaludin, M. H., Shazani, S.,Mohammad Amizi A., Lee S. W., Mohd Sukhairi Mat Rasat, M. Mazlan, A.M. Iqbal, Ahmad Anwar Ismail, N. N. Azwanida, M. Marwan \&M. Farhan. 
2014. A Study on the Anatomy Features of Green and Dark Brown Buffalo Leech (Hirudinea manillensis). Journal of Sustainability Science and Management 9(1): 134-140.

406th Medical Laboratory special report on Blood Sucking Asia Leeches of Families Hirudidae \& Haemadipsidae, July 1968. United States Army Medical Command, Japan. 